Article

\title{
Analysis of Physical and Biogeochemical Control Mechanisms on Summertime Surface Carbonate System Variability in the Western Ross Sea (Antarctica) Using In Situ and Satellite Data
}

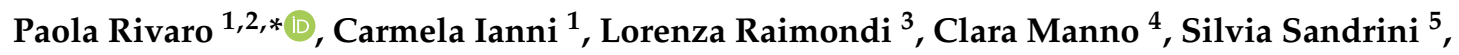 \\ Pasquale Castagno $^{6}(\mathbb{D})$, Yuri Cotroneo ${ }^{2,6}{ }^{(D)}$ and Pierpaolo Falco ${ }^{2,6}(\mathbb{D}$ \\ 1 Department of Chemistry and Industrial Chemistry, University of Genoa, via Dodecaneso 31, \\ 16146 Genova, Italy; ianni@chimica.unige.it \\ 2 CoNISMa Consortium, Piazzale Flaminio 9, 00196, Rome, Italy; yuri.cotroneo@uniparthenope.it (Y.C.); \\ pierpaolo.falco@uniparthenope.it (P.F.) \\ 3 Department of Oceanography, Dalhousie University Steele Ocean Sciences Building (SOSB), \\ 1355 Oxford Street, Halifax, NS B3H 4R2, Canada; Lorenza.Raimondi@Dal.Ca \\ 4 British Antarctic Survey Madingley Road, High Cross, Cambridge CB3 0ET, UK; clanno@bas.ac.uk \\ 5 National Research Council of Italy, ISAC, Via Gobetti 101, 40129 Bologna, Italy; S.Sandrini@isac.cnr.it \\ 6 Department of Science and Technology, Parthenope University of Naples, Centro Direzionale, Isola C4, \\ 80143 Napoli, Italy; pasquale.castagno@uniparthenope.it \\ * Correspondence: rivaro@chimica.unige.it; Tel.: +39-010-3536172
}

Received: 11 January 2019; Accepted: 21 January 2019; Published: 24 January 2019

\begin{abstract}
In this study, carbonate system properties were measured in the western Ross Sea (Antarctica) over the 2005-2006 and 2011-2012 austral summers with the aim of analysing their sensitivity to physical and biogeochemical drivers. Daily Advanced Microwave Scanning Radiometer 2 (AMSR2) sea ice concentration maps, obtained prior to and during the samplings, were used to analyse the sea ice evolution throughout the experiment periods. Monthly means and 8-day composite chlorophyll concentration maps from the Moderate-resolution Imaging Spectroradiometer (MODIS) Aqua satellite at 4-km resolution were used to investigate inter-annual and basin scale biological variability. Chlorophyll-a concentrations in surface waters estimated by MODIS satellite data contribute to descriptions of the variability of carbonate system properties in surface waters. Mean values of carbonate system properties were comparable across both investigated years; however, the 2012 data displayed larger variability. Sea ice melting also had a pivotal role in controlling the carbonate system chemistry of the mixed layer both directly through dilution processes and indirectly by favouring the development of phytoplankton blooms. This resulted in high $\mathrm{pH}$ and $\Omega_{\mathrm{Ar}}$, and in low $C_{T}$, particularly in those areas where high chlorophyll concentration was shown by satellite maps.
\end{abstract}

Keywords: carbonate system; Ross Sea; Antarctic surface waters; air-sea $\mathrm{CO}_{2}$ exchange; satellite sea ice data; satellite chlorophyll maps

\section{Introduction}

The Southern Ocean $(\mathrm{SO})$ is highly sensitive to anthropogenic atmospheric carbon dioxide $\left(\mathrm{CO}_{2}\right)$ increases, as the cold waters are naturally $\mathrm{CO}_{2}$-rich and have a low total alkalinity $\left(\mathrm{A}_{\mathrm{T}}\right)$ to total inorganic carbon $\left(\mathrm{C}_{\mathrm{T}}\right)$ ratio, which then reduces the degree of carbonate mineral saturation and the buffering capacity for further $\mathrm{CO}_{2}$ uptake [1,2]. The addition of $\mathrm{CO}_{2}$ to seawater increases $\mathrm{C}_{\mathrm{T}}$, bicarbonate $\left(\mathrm{HCO}_{3}{ }^{-}\right)$, and hydrogen $\left(\mathrm{H}^{+}\right)$ion concentrations, and decreases carbonate $\left(\mathrm{CO}_{3}{ }^{2-}\right)$ ion concentration and $\mathrm{pH}$. Furthermore, $\mathrm{CO}_{2}$ addition lowers the saturation state $(\Omega)$ of calcium carbonate 
in a process called ocean acidification (OA) [3,4]. Surface waters of the SO are predicted to experience wintertime carbonate under-saturation, which is driven by seasonal variations in biological activities and a combination of reduced sea-ice cover, surface water freshening, and increased air-sea $\mathrm{CO}_{2}$ exchange, by 2030 [5,6]. These changes in carbonate chemistry could have severe consequences for calcifying organisms. Indeed, live shell dissolution of shelled pteropods in the SO has been already reported $[5,7,8]$.

The Ross Sea continental shelf is of critical importance to global biogeochemical cycles and in $\mathrm{CO}_{2}$ uptake because of its leading role in the primary production of the $\mathrm{SO}[9,10]$ and in the formation of Antarctic bottom water (AABW), which impacts the climate on a regional and global scale [11,12]. Both numerical models [13] and in situ observations [1,14,15] confirm that the Ross Sea shelf area is an important $\mathrm{CO}_{2}$ sink region at an annual scale due to its high biological productivity, intense winds, and high bottom water ventilation rates.

The variability of the carbonate system in Ross Sea surface waters (Antarctic surface water (AASW) ) has been reported at both the large scale and mesoscale [16-20]. Observations carried out during summertime suggest that the carbonate system is primarily controlled by biological activities (such as primary production). However, the lowest $\Omega$ observed close to the glacier fronts suggests that the increasing glacier melt could counteract the effects of primary production because the freshening of surface water due to dilution leads to less $\mathrm{CO}_{3}{ }^{2-}$ [21].

Furthermore, the variability of surface carbonate system properties in the Antarctic region on interannual and shorter timescales could be influenced by the Southern Annular Mode (SAM) and the El Niño-Southern Oscillation (ENSO) [22]. Both phenomena influence several aspects of the general circulation of the SO at different spatial and temporal scales [23-26].

Here we present carbonate system data from samples collected during the Italian Climatic Long-term Interaction for Mass-balance in Antarctica (CLIMA, 2005-2006) and Terra Nova Bay Research Experiment (T-REx, 2011-12) research cruises. We analyse the sensitivity of the carbonate system to physical and biogeochemical drivers by comparing chemical data with in situ oceanographic measurements and satellite sea ice and chlorophyll-a (Chl-a) data on the Ross Sea continental shelf during summer.

Satellite ocean-colour data, along with data from other remote sensing platforms, are useful in remote areas (such as the high-latitude polar regions) to study the interannual changes that characterize phytoplankton dynamics. However, it is essential to complement remotely sensed data with an in situ sample collection program to understand the mechanisms that govern variability and to ensure the accuracy of satellite-derived measurements.

This multiplatform approach has been already used to describe both large and mesoscale phenomena at all latitudes [20,27-29]. Principal component analysis (PCA) is then used to evaluate relationships and differences among stations and between the two summer seasons with regards to physical and biochemical variables and to AASW properties.

\section{Materials and Methods}

\subsection{Sampling}

In situ data were collected during two R.V. Italica cruises in the framework of the CLIMA and T-REx projects of the Italian National Program of Research in Antarctica. Both cruises were carried out on the Ross Sea continental shelf with the aim of describing the main physical and bio-geo-chemical properties of the water masses along the water column. The sampling plan was designed both to cover different areas during the same season and to repeat stations to characterize the interannual variability of selected areas such as the Terra Nova Bay polynya. A total of 162 CTD (Conductivity Temperature Depth) casts (CLIMA cruise, 1 January-12 February 2006) and 62 CTD casts (T-REx cruise, 23 January-9 February 2012) were performed during each cruise. In the present work, a subset of CTD stations were selected to compare data collected in similar locations during the 2006 and 2012 
cruises. Thus, we investigated twenty-five and twenty-nine stations of the CLIMA and T-REx cruises, respectively (Figure 1). The selected sampling stations are located along the Ross Ice Shelf (RIS), within the Ross Sea polynya area (RSp) between Terra Nova Bay and McMurdo Sound, and along the western coast of the Ross Sea. A series of transects crossing the Drygalski Trough were made in the Terra Nova Bay polynya (TNBp), north of Coulman Island (CI), and at the continental shelf break off Cape Adare (CA). At each station, water samples for carbonate system analyses were collected at 5-7 depths (from the surface to the bottom) using 12-L Niskin bottles and were stored in 500-mL borosilicate glass bottles following standard operating procedures [30]. The water samples were then poisoned with saturated $\mathrm{HgCl}_{2}$ solution to stop biological activity from altering the carbon distribution before analysis. Samples were finally stored at constant temperature $\left(+4^{\circ} \mathrm{C}\right)$ in dark conditions.

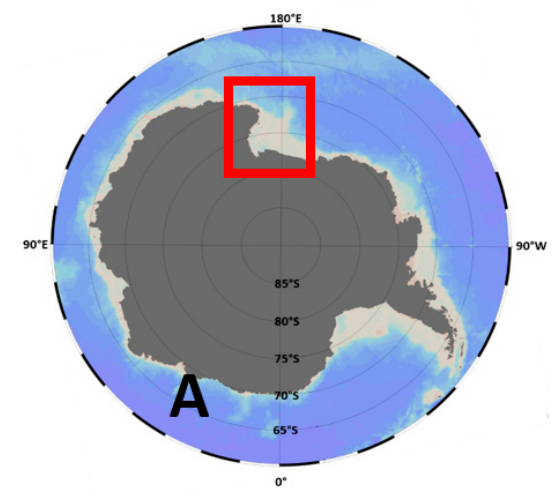

(a)

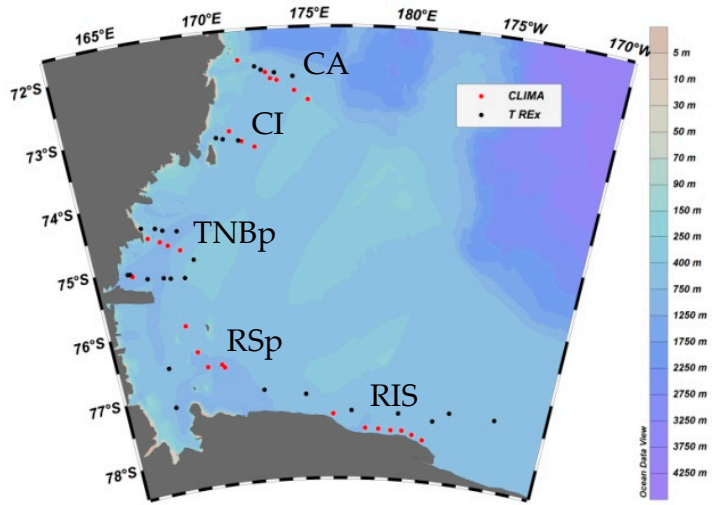

(b)

Figure 1. (a) Location of the Ross Sea, Antarctica. (b) Map of the sampling stations of the Climatic Long-term Interaction for Mass-balance in Antarctica (CLIMA) cruise (red dots: 1 January-12 February 2006) and of the Terra Nova Bay Research Experiment (T-Rex) cruise (black dots: 23 January-9 February 2012) in the Ross Sea. Investigated areas discussed in the text are indicated as: Cape Adare, CA; Coulman Island, CI; Terra Nova Bay polynya, TNBp; Ross Sea polynya, RSp; Ross ice shelf, RIS.

\section{2. $A_{T}, C_{T}$, and $p H$ Measurements}

For samples collected during the CLIMA survey, total alkalinity $\left(\mathrm{A}_{\mathrm{T}}\right)$ and total inorganic carbon $\left(C_{T}\right)$ were measured simultaneously by using a potentiometric titration system $[30,31]$. For samples collected during the T-REx survey, $\mathrm{A}_{\mathrm{T}}$, and $\mathrm{pH}$ were measured using the methods described in [32,33]. The $\mathrm{pH}$ was expressed using the $\mathrm{pH}$ total scale (i.e., $\left[\mathrm{H}^{+}\right]$as moles per kilogram of seawater, $\mathrm{pH}_{\mathrm{T}}$ ) and was determined using a potentiometric method that employed a combination of glass/reference electrode and NTC ((Negative Temperature Coefficient) temperature sensor. The tris(hydroxymethyl)aminomethane (TRIS) buffer used to standardize the $\mathrm{pH}$ electrode was prepared according to [30]. Before the measurements were conducted, both the TRIS buffer and seawater samples were brought to the same temperature $\left(25 \pm 0.1^{\circ} \mathrm{C}\right)$ using a thermostatic water bath. The $\mathrm{pH}_{\mathrm{T}}$ measurements at $25^{\circ} \mathrm{C}$ were then recalculated at in situ temperature and pressure conditions $\left(\mathrm{pH}_{\mathrm{in} \text { situ }}\right)$.

The accuracy and precision of $\mathrm{A}_{\mathrm{T}}$ and $\mathrm{C}_{\mathrm{T}}$ measurements were evaluated using different Certified Reference Material batches (CRM batches 58, 95, and 123) provided by Prof. A. G. Dickson (Scripps Institution of Oceanography). For 2006 samples the accuracy was $\pm 4.0 \mu \mathrm{mol} \mathrm{kg}{ }^{-1}$ for both $A_{T}$ and $C_{T}$ and the precision was $\pm 3.0 \mu \mathrm{mol} \mathrm{kg}{ }^{-1}$ for $A_{T}$ and $\pm 4.0 \mu \mathrm{mol} \mathrm{kg}{ }^{-1}$ for $C_{T}$, respectively. Measurements for 2012 samples were characterized by an accuracy and precision of $\pm 4.0 \mu \mathrm{mol} \mathrm{kg}-1$ for $\mathrm{A}_{\mathrm{T}}$. The accuracy of the $\mathrm{pH}$ measurements would have been strongly dependent on the composition of the TRIS buffer solution, but no certified material was available. Therefore, this figure of merit was not determined. The precision of the $\mathrm{pH}$ measurement was \pm 0.007 units and was evaluated by repeated analysis of the $\mathrm{A}_{\mathrm{T}}$ certified material. 


\section{3. $\mathrm{CO}_{2}$-Carbonate System}

The $\mathrm{CO}_{2}$ SYS program was used to calculate seawater $\mathrm{pCO}_{2}$ and $\Omega$ data from the measured variables [34]. In addition, $\mathrm{pH}$ values were calculated from $\mathrm{A}_{T}$ and $\mathrm{C}_{T}$ for the 2006 dataset and $C_{T}$ concentrations from $\mathrm{A}_{\mathrm{T}}$ and $\mathrm{pH}$ for the 2012 dataset. Equilibrium constants of $\mathrm{CO}_{2}(\mathrm{~K} 1$ and K2) and total hydrogen ion scale $\left(\mathrm{mol} \mathrm{kg-SW}{ }^{-1}\right)$ for $\mathrm{pH}$ were used for the calculations [35].

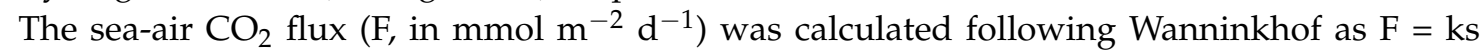
$\left(\triangle \mathrm{pCO}_{2}\right)$, where $\mathrm{k}$ is the $\mathrm{CO}_{2}$ gas transfer velocity $\left(\mathrm{cm} \mathrm{h}^{-1}\right)$, $\mathrm{s}$ is the solubility of $\mathrm{CO}_{2}\left(\mathrm{~mol} \mathrm{~kg}^{-1} \mathrm{~atm}^{-1}\right)$ and $\triangle \mathrm{pCO}_{2}$ is the difference between $\mathrm{pCO}_{2 \mathrm{SW}}$ and $\mathrm{pCO}_{2 \mathrm{~atm}}$ [36]. Ship-based wind speed data at $25 \mathrm{~m}$ height were used to calculate the gas transfer velocity $(\mathrm{k})$. The seawater $\mathrm{pCO}_{2}$ data were calculated from the measured inorganic carbon data obtained in this study, whereas the atmospheric $\mathrm{pCO}_{2}$ data (383 and $392.61 \mu \mathrm{atm}$ for 2006 and 2012, respectively) were obtained from the South Pole Observatory dataset (http:/ / www.esrl.noaa.gov/gmd/dv/data/index) and corrected to $100 \%$ humidity at in situ sea surface temperature (SST) and salinity. All corrections and calculations of $\mathrm{CO}_{2}$ flux were carried out as described in [33].

\subsection{Hydrographic and Ancillary Data}

Conductivity, temperature, and depth were acquired using a CTD profiler Sea Bird Electronics SBE 9/11plus. The CTD was equipped with dual temperature-conductivity sensors and with an SBE $23 \mathrm{O} 2$ sensor and Chelsea Aquatrack III fluorometer for oxygen concentration and fluorescence data. The CTD calibrations were performed before and after both cruises. Data were acquired at the maximum frequency $(24 \mathrm{~Hz})$ with a descent speed of $1 \mathrm{~m} \mathrm{~s}^{-1}$. The data were corrected and processed according to international procedures [37]. Potential temperature $(\theta)$ and salinity $(S)$ were computed using standard algorithms [38]. The data were processed and quality checked using the CTD Sea Bird Electronics data processing software. Finally, the profiles were vertically averaged over $1 \mathrm{~m}$ depth bins.

Melt water percentage in the upper surface layer (MW\%) was calculated assuming an average sea-ice salinity of six [39] and considering the difference between the salinity measured at the surface $\left(\mathrm{S}_{\text {meas }}\right)$ and the salinity measured at the same station at greater depth $\left(\mathrm{S}_{\text {deep }}\right)$, where this is not influenced by freshening due to sea-ice melting.

Mixed layer (ML) depth was determined for each cast by considering an increase in in situ density anomaly $\left(\sigma_{t}\right)>0.05$ over a $5 \mathrm{~m}$ depth interval, which has been successfully applied in the same area in previous papers $[20,40,41]$.

\subsection{Statistical Analysis}

Pair-wise Pearson correlation coefficients were computed to examine the relationships between the parameters. The multivariate statistical technique principal component analysis (PCA) was used to evaluate the correlations between variables and differences among samples collected in the AASW. By means of PCA, a data matrix was reduced to smaller ones that consisted of principal component (PC) loadings and scores. PC scores condense information about all variables into a single number, whereas PC loadings are the eigenvectors of the correlation and indicate the relative contribution of each variable to that score [42]. PCA was performed on a total of 123 samples. The dataset was structured based on three main variables groups: physical and chemical variables $\left(\theta\right.$, salinity, fluorescence, $\mathrm{O}_{2}$, $\mathrm{A}_{\mathrm{T}}, \mathrm{C}_{\mathrm{T}}, \mathrm{pH}$, and $\mathrm{pCO}_{2}$ ), sampling years (2006 and 2012), and sampling areas (TNBp, RIS, CA, CI, and RSp). Statistical analysis and PCA were carried out using the Statistica Pro package (StatSoft, Inc., 2001) and the differences were deemed statistically significant at $p=0.05$. Chemical and physical data were presented using Ocean Data View software [43]. 


\subsection{Satellite Data}

Satellite Chl-a concentration maps estimated through the OCI algorithm from a Level 3 Aqua MODIS product were used (http: / / oceancolor.gsfc.nasa.gov/cgi/13) to complement in situ fluorescence data and to investigate inter-annual variability. Moreover, remotely sensed data allowed for the observation of the spatial variability at a larger scale. Monthly mean Chl-a maps were used to discuss basin scale Chl-a patterns during February 2006 and February 2012. Additionally, in order to compare in situ data with the closest in time and nearest in space satellite data, 8-day composite at 4-km resolution maps for the Ross Sea area during the sampling periods in 2006 and 2012 were used.

Sea ice concentration and evolution were analysed through daily satellite Advanced Microwave Scanning Radiometer 2 (AMSR2) sea ice concentration maps, provided at 3.125-km resolution by the University of Bremen for weeks previous to or contemporaneous with the sampling (http:/ / iup. physik.uni-bremen.de/iuppage/psa/2001/amsrop.html) [44].

\section{Results}

\subsection{Hydrographic and Carbonate Chemistry Variability}

Water masses were identified and defined according to [12]. AASW is characterised by a neutral density $\left(\gamma^{\mathrm{n}}\right)<28.00 \mathrm{~kg} \mathrm{~m}^{-3}$ and $\mathrm{S}<34.30$. Circumpolar deep water (CDW) is defined by $28.00<\gamma^{\mathrm{n}}<$ $28.27 \mathrm{~kg} \mathrm{~m}^{-3}$ and by a subsurface potential temperature maximum (Figure 2) [45]. The CDW intrudes onto the continental shelf area in the middle layer between the lighter AASW and the densest shelf waters below (i.e., high salinity shelf waters (HSSW) and/or ice shelf water (ISW) [46]. As expected, the larger variability observed in surface water physical properties compared to deep water characteristics is mainly connected to the intense interactions occurring the ocean-atmosphere-ice interface $[47,48]$. Table 1 reports mean, standard deviation, minimum, and maximum values of the physical properties of the AASW (i.e., $\gamma^{\mathrm{n}}<28.00 \mathrm{~kg} \mathrm{~m}^{-3}$ ).

Table 1. Mean, standard deviation (st.d.), minimum (min) and maximum (max) values of potential temperature $\left(\theta,{ }^{\circ} \mathrm{C}\right)$, salinity $(\mathrm{S})$, melt water percentage (MW\%), Antarctic surface water (AASW) thickness (m) and mixer layer (ML) depth (m).

\begin{tabular}{|c|c|c|c|c|c|c|c|c|c|c|c|}
\hline 2006 & $\theta$ & $S$ & MW\% & AASW & ML & 2012 & $\theta$ & $S$ & MW\% & AASW & ML \\
\hline TNBp & & & & & & TNBp & & & & & \\
\hline Mean & 0.77 & 34.07 & 2.6 & 19 & 14 & Mean & -0.86 & 33.97 & 3.7 & 34 & 13 \\
\hline st.d. & 0.88 & 0.34 & 1.4 & 2 & 2 & st.d. & 0.49 & 0.56 & 2.3 & 7 & 7 \\
\hline $\min$ & -1.01 & 33.15 & 1.5 & 17 & 11 & $\min$ & -1.77 & 32.49 & 0.3 & 21 & 7 \\
\hline $\max$ & 2.24 & 34.53 & 4.9 & 22 & 16 & $\max$ & 0.36 & 34.55 & 6.5 & 44 & 32 \\
\hline RSp & & & & & & RSp & & & & & \\
\hline Mean & 0.17 & 34.41 & 0.8 & 42 & 23 & Mean & -1.01 & 33.90 & 4.5 & 37 & 10 \\
\hline st.d. & 0.75 & 0.12 & 1.2 & 15 & 21 & st.d. & 0.54 & 0.48 & 0.4 & 10 & 3 \\
\hline $\min$ & -1.12 & 33.73 & 0.1 & 23 & 4 & $\min$ & -1.66 & 33.04 & 4.3 & 30 & 7 \\
\hline $\max$ & 3.05 & 34.50 & 2.6 & 57 & 49 & $\max$ & 0.25 & 34.49 & 4.8 & 44 & 16 \\
\hline RIS & & & & & & RIS & & & & & \\
\hline Mean & -1.07 & 34.32 & 0.9 & 197 & 67 & Mean & -1.19 & 34.24 & 1.8 & 321 & 116 \\
\hline st.d. & 0.46 & 0.08 & 0.2 & 35 & 24 & st.d. & 0.62 & 0.13 & 0.5 & 100 & 56 \\
\hline $\min$ & -1.66 & 34.20 & 0.4 & 132 & 50 & $\min$ & -1.83 & 33.78 & 0.8 & 183 & 45 \\
\hline $\max$ & -0.46 & 34.45 & 1.0 & 228 & 84 & $\max$ & 0.29 & 34.45 & 2.3 & 446 & 198 \\
\hline CI & & & & & & CI & & & & & \\
\hline Mean & -0.56 & 34.20 & 1.8 & 55 & 35 & Mean & -0.77 & 34.16 & 2.2 & 107 & 32 \\
\hline st.d. & 0.51 & 0.19 & 0.9 & 8 & 4 & st.d. & 0.55 & 0.29 & 1.0 & 18 & 6 \\
\hline $\min$ & -1.59 & 33.74 & 0.9 & 46 & 30 & $\min$ & -1.55 & 33.55 & 1.0 & 89 & 29 \\
\hline $\max$ & 0.11 & 34.48 & 2.6 & 61 & 40 & $\max$ & 0.24 & 34.47 & 3.2 & 132 & 50 \\
\hline CA & & & & & & CA & & & & & \\
\hline Mean & -0.54 & 34.34 & 1.1 & 143 & 21 & Mean & -0.88 & 34.24 & 1.5 & 209 & 41 \\
\hline st.d. & 0.28 & 0.09 & 0.1 & 33 & 18 & st.d. & 0.37 & 0.18 & 0.1 & 36 & 5 \\
\hline $\min$ & -1.45 & 34.18 & 0.9 & 35 & 19 & $\min$ & -1.49 & 33.55 & 1.3 & 172 & 36 \\
\hline $\max$ & 0.25 & 34.54 & 1.3 & 204 & 24 & $\max$ & 0.18 & 34.54 & 1.6 & 251 & 45 \\
\hline
\end{tabular}


The AASW mean temperature and salinity were higher in the summer of 2006 than in 2012 in all the studied areas. The warmest values were observed in TNBp and RSp in 2006, while RIS was the coldest area during both surveys. The observed thermohaline variability is coherent with the higher MW\% calculated for 2012. These differences in hydrographic properties were reflected along the entire AASW layer and had an impact on the observed ML depths, as will be further discussed. Furthermore, the AASW layer thickness changed from 2006 to 2012. The mean thicknesses of each area for the CLIMA survey (2006) were lower than those for the T-REx survey (2012). In particular, the-AASW thickness values in 2006 in the TNBp and at the CI stations were about half of 2012 's values. The shallowest AASW layer was found for both surveys in the TNBp and it deepened moving from the TNBp toward CA and the RIS (cf. Table 1). Additionally, a very shallow ML was calculated for the TNBp stations in both surveys. Conversely, deeper and more variable ML depths were calculated for the other surveyed areas (Table 1).

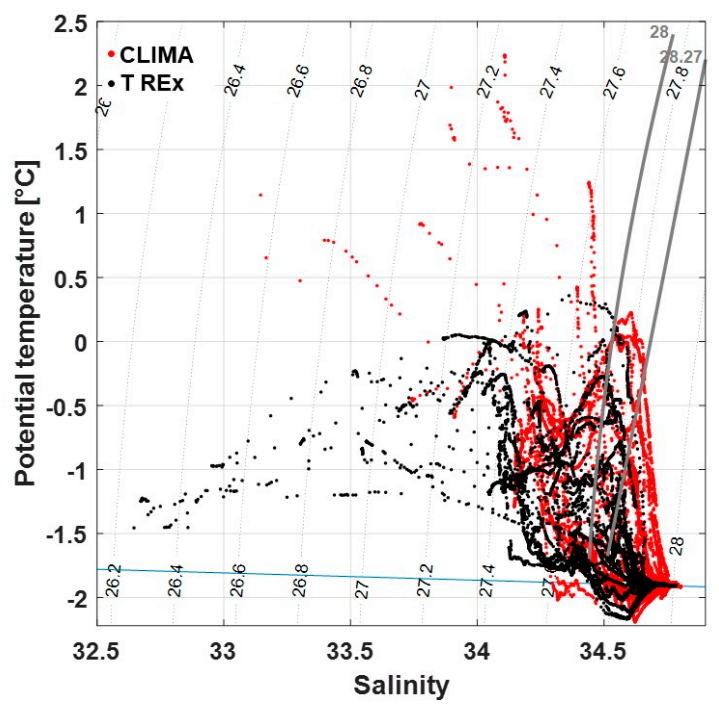

Figure 2. Potential temperature salinity $(\theta / S)$ plot for the sampled stations in 2006 (red dots) and in 2012 (black dots).

Furthermore, the physical properties of the intermediate and deep waters during the two cruises were more similar and varied within a relatively narrow range (cf. Figure 2) compared to the AASW.

The intrusion of CDW was traced in 2006 and 2012 to near CA by a relative $\theta$ subsurface maximum in the expected $\gamma^{\mathrm{n}}$ range between 28.00 and $28.27 \mathrm{~kg} \mathrm{~m}^{-3}$. The same intrusion has also been successively observed when analysing the long time series of mooring data collected in the areas of the T-REx and CLIMA surveys (www.morsea.uniparthenope.it, mooring G) [46]. Water masses with $\theta$ below $-2.0^{\circ}$ $\mathrm{C}$ found in both surveys at $\sim 400 \mathrm{~m}$ along the RIS were associated with deep ice shelf water (DISW) outflow. Finally, the HSSW, found in the TNBp and in several stations both in the RSp and CI, was characterized by salinity values higher than 34.75 .

During both cruises a general increase with depth was observed for $A_{T}$ and $C_{T}$ whereas a decrease for $\mathrm{pH}$ was found (Figure $3 \mathrm{a}-\mathrm{c}$ ). All samples were oversaturated with respect to both the calcite and the aragonite; $\Omega$ aragonite $\left(\Omega_{\mathrm{Ar}}\right)$ values near the equilibrium $(\sim 1.0)$ were found in the deepest layers of the TNBp (Figure 3d).

All the parameters showed high variability in the upper layer of the water column (from the surface down to a depth of more than $100 \mathrm{~m}$ ). On the contrary, the carbonate system data of the intermediate and deep waters during the two cruises showed similar values and varied within a relatively narrow range. These patterns are in good agreement with other measurements collected during the summer season in the Ross Sea [18-20,33,49]. 
$A_{T}$ and $S$ were found to be significantly and positively correlated (Pearson's $r=0.76, n=328$ ) in the HSSW layer at depths greater than $500 \mathrm{~m}$ in TNBp stations and along its spreading pathways. This is due to $A_{T}$ conservative behavior with respect to $S$. The $\mathrm{pH}$ co-varied positively and significantly with $\theta$ and $\mathrm{O}_{2}$ (Pearson's $\mathrm{r}=0.27$ and 0.46 , respectively, $\mathrm{n}=328$ ) and negatively with $\mathrm{S}(-0.42)$. Conversely, $\mathrm{C}_{\mathrm{T}}$ co-varied negatively with $\theta$ and $\mathrm{O}_{2}$ (Pearson's $\mathrm{r}=-0.51$ and -0.61 , respectively, $\mathrm{n}=328$ ) and positively with $S(0.72)$.

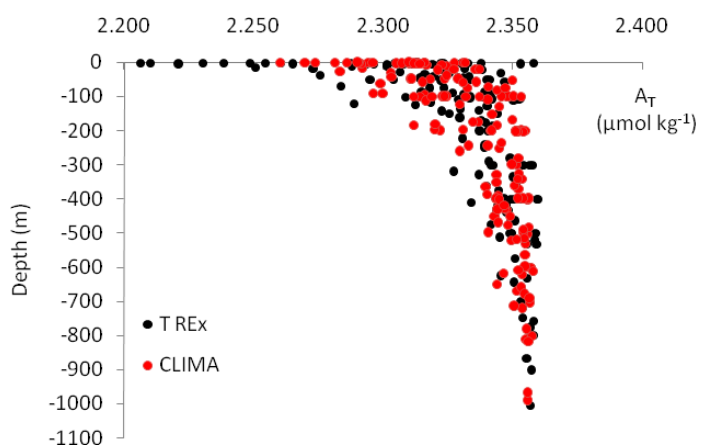

(a)

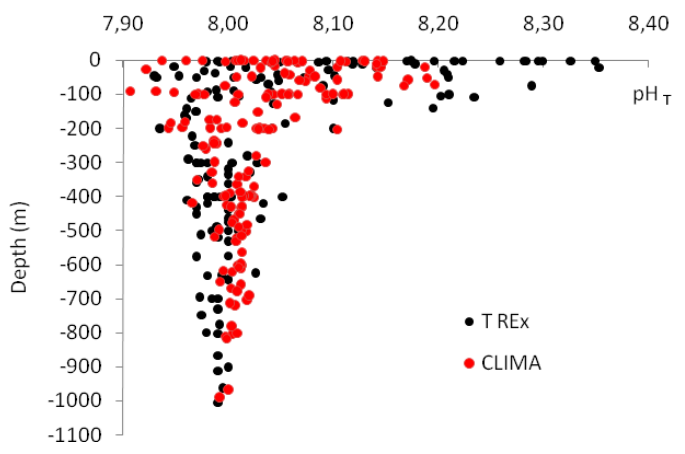

(c)

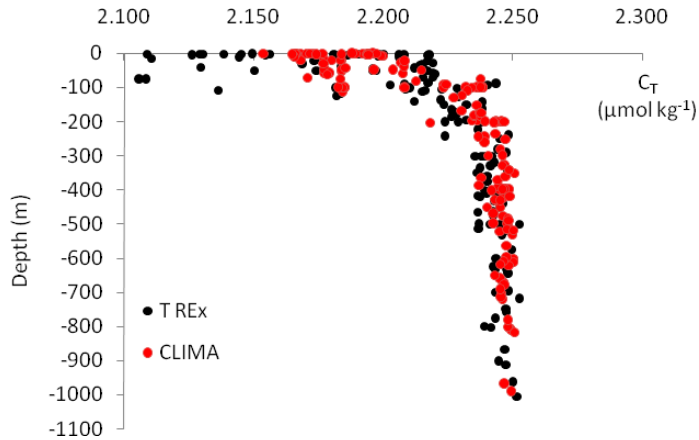

(b)

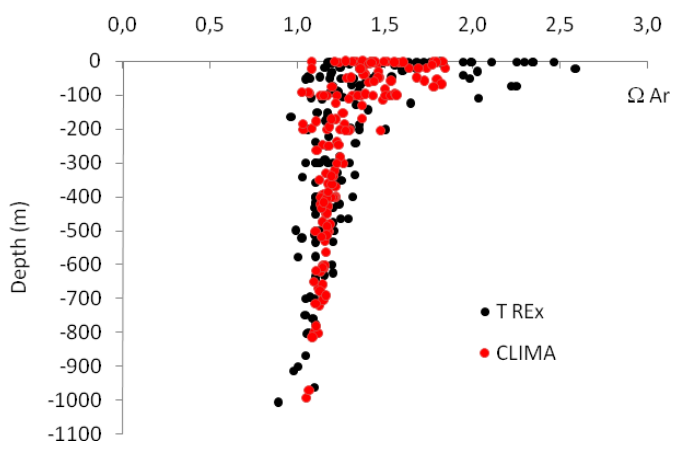

(d)

Figure 3. Vertical distribution of (a) total alkalinity $\left(\mathrm{A}_{\mathrm{T}}\right)$, (b) total inorganic carbon $\left(\mathrm{C}_{\mathrm{T}}\right),(\mathbf{c}) \mathrm{pH}_{\text {in situ }}$, and (d) aragonite saturation state $\left(\Omega_{\mathrm{Ar}}\right)$ (red dots: CLIMA samples; black dots: T-REx samples).

Table 2 reports the ranges of the carbonate system properties measured in the AASW layer of the investigated areas. Mean data of the carbonate system properties are comparable but 2012 data are more scattered, particularly for those in the TNBp, according to both the standard deviation and the range of the observed values.

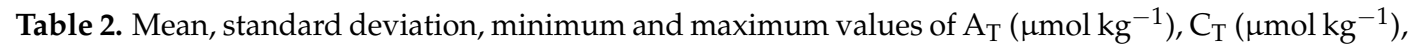
$\mathrm{pH}_{\text {in situ }}, \mathrm{pCO}_{2}$ ( $\mu$ atm), $\Omega$ calcite $\left(\Omega_{\mathrm{Ca}}\right)$, and $\Omega$ aragonite $\left(\Omega_{\mathrm{Ar}}\right)$ in the AASW.

\begin{tabular}{|c|c|c|c|c|c|c|c|c|c|c|c|c|c|}
\hline 2006 & $\mathbf{A}_{T}$ & $\mathrm{C}_{\mathrm{T}}$ & $\mathrm{pH}_{\text {in situ }}$ & $\mathrm{pCO}_{2}$ & $\Omega_{\mathrm{Ca}}$ & $\Omega_{\mathrm{Ar}}$ & 2012 & $\mathbf{A}_{\mathbf{T}}$ & $\mathrm{C}_{\mathrm{T}}$ & $\mathrm{pH}_{\text {in situ }}$ & $\mathrm{pCO}_{2}$ & $\Omega_{\mathrm{Ca}}$ & $\Omega_{\mathrm{Ar}}$ \\
\hline TNBp & & & & & & & TNBp & & & & & & \\
\hline Mean & 2297.9 & 2170.5 & 8.06 & 376 & 2.4 & 1.5 & Mean & 2307.8 & 2175.8 & 8.11 & 341 & 2.5 & 1.6 \\
\hline st.d. & 26.4 & 8.2 & 0.07 & 59 & 0.3 & 0.2 & st.d. & 51.3 & 73.7 & 0.11 & 96 & 0.7 & 0.4 \\
\hline $\min$ & 2260.2 & 2154.0 & 8.01 & 266 & 2.1 & 1.3 & $\min$ & 2210.0 & 2015.3 & 7.95 & 172 & 1.8 & 1.4 \\
\hline $\max$ & 2337.1 & 2179.9 & 8.19 & 419 & 2.9 & 1.8 & $\max$ & 2376.4 & 2284.6 & 8.35 & 505 & 3.7 & 2.3 \\
\hline RSp & & & & & & & $\mathrm{RSp}$ & & & & & & \\
\hline Mean & 2320.6 & 2171.6 & 8.11 & 333 & 2.7 & 1.7 & Mean & 2282.2 & 2188.7 & 8.29 & 205 & 3.4 & 2.1 \\
\hline st.d. & 20.9 & 6.6 & 0.07 & 66 & 0.3 & 0.2 & st.d. & 31.3 & 28.8 & 0.01 & 4 & 0.4 & 0.3 \\
\hline $\min$ & 2331.5 & 2183.3 & 8.15 & 480 & 2.1 & 1.3 & $\min$ & 2260.2 & 2164.4 & 8.28 & 202 & 3.0 & 1.4 \\
\hline $\max$ & 2273.6 & 2165.7 & 7.96 & 297 & 2.9 & 1.8 & $\max$ & 2304.4 & 2209.1 & 8.30 & 208 & 3.6 & 2.5 \\
\hline
\end{tabular}


Table 2. Cont

\begin{tabular}{|c|c|c|c|c|c|c|c|c|c|c|c|c|c|}
\hline 2006 & $\mathbf{A}_{\mathrm{T}}$ & $\mathrm{C}_{\mathrm{T}}$ & $\mathrm{pH}_{\text {in situ }}$ & $\mathrm{pCO}_{2}$ & $\Omega_{\mathrm{Ca}}$ & $\Omega_{\mathrm{Ar}}$ & 2012 & $\mathbf{A}_{\mathbf{T}}$ & $\mathrm{C}_{\mathrm{T}}$ & $\mathrm{pH}_{\text {in situ }}$ & $\mathrm{pCO}_{2}$ & $\Omega_{\mathrm{Ca}}$ & $\Omega_{\mathrm{Ar}}$ \\
\hline RIS & & & & & & & RIS & & & & & & \\
\hline Mean & 2312.0 & 2200.9 & 8.04 & 391 & 2.1 & 1.3 & Mean & 2322.0 & 2160.9 & 8.22 & 255 & 3.1 & 2.0 \\
\hline st.d. & 8.5 & 23.0 & 0.06 & 62 & 0.3 & 0.2 & st.d. & 10.4 & 89.0 & 0.10 & 52 & 0.5 & 0.3 \\
\hline $\min$ & 2295.9 & 2164.9 & 7.91 & 305 & 1.6 & 1.0 & $\min$ & 2304.4 & 2074.3 & 8.10 & 175 & 2.4 & 1.5 \\
\hline $\max$ & 2329.3 & 2237.5 & 8.13 & 530 & 2.6 & 1.6 & $\max$ & 2341.6 & 2464.7 & 8.35 & 339 & 4.1 & 2.6 \\
\hline CI & & & & & & & CI & & & & & & \\
\hline Mean & 2302.8 & 2201.4 & 8.00 & 425 & 2.0 & 1.3 & Mean & 2291.4 & 2195.1 & 8.00 & 441 & 2.0 & 1.2 \\
\hline st.d. & 24.5 & 6.9 & 0.06 & 65 & 0.3 & 0.2 & st.d. & 40.9 & 45.2 & 0.05 & 55 & 0.2 & 0.2 \\
\hline $\min$ & 2270.0 & 2192.5 & 7.92 & 358 & 1.7 & 1.1 & $\min$ & 2220.8 & 2126.1 & 7.91 & 374 & 1.6 & 1.0 \\
\hline $\max$ & 2330.6 & 2208.0 & 8.07 & 514 & 2.3 & 1.4 & $\max$ & 2340.8 & 2274.7 & 8.07 & 556 & 2.4 & 1.5 \\
\hline CA & & & & & & & CA & & & & & & \\
\hline Mean & 2315.0 & 2192.7 & 8.06 & 370 & 2.3 & 1.4 & Mean & 2308.8 & 2203.9 & 8.02 & 417 & 2.1 & 1.3 \\
\hline st.d. & 12.6 & 8.7 & 0.04 & 40 & 0.2 & 0.2 & st.d. & 12.3 & 21.1 & 0.04 & 46 & 0.2 & 0.1 \\
\hline $\min$ & 2290.3 & 2182.6 & 7.98 & 321 & 1.9 & 1.2 & $\min$ & 2293.2 & 2174.1 & 7.94 & 352 & 1.8 & 1.1 \\
\hline $\max$ & 2332.1 & 2208.5 & 8.11 & 453 & 2.5 & 1.6 & $\max$ & 2330.4 & 2237.8 & 8.09 & 497 & 2.4 & 1.5 \\
\hline
\end{tabular}

\subsection{Data Analysis}

Principal component analysis led to the identification of three principal components explaining about $80 \%$ of the total variance, which is valuable for the exploratory data analysis performed in this study and comparable to previous studies [39]. Figure 4 shows the loading plots of these PCs: $C_{T}$ and $\mathrm{O}_{2}$ load on $\mathrm{PC} 1 ; \mathrm{S}, \mathrm{A}_{\mathrm{T}}, \mathrm{pCO}_{2}$, and $\mathrm{pH}$ load on both PC2 and PC3; and fluorescence and $\theta$ are found on PC3.

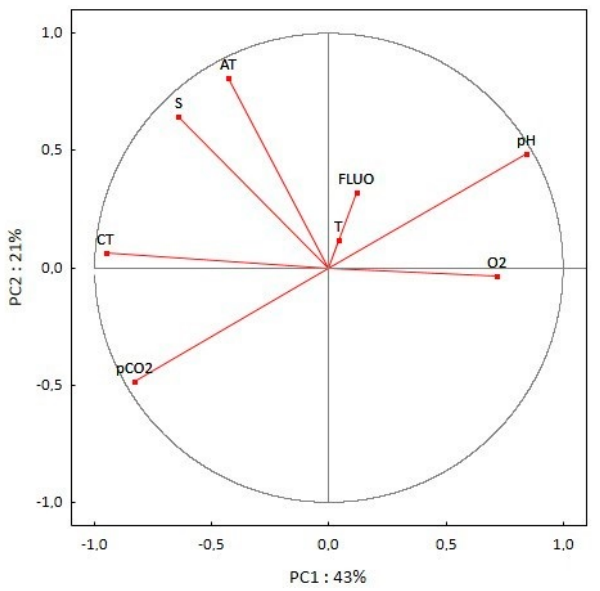

(a)

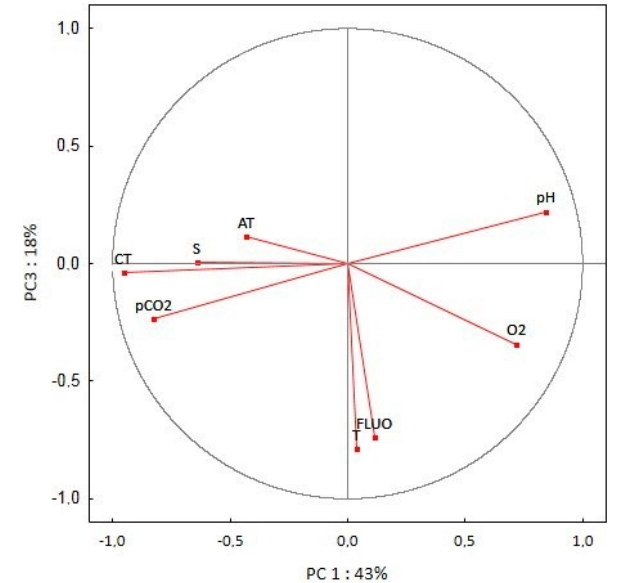

(b)

Figure 4. Plots of principal component analysis (PCA) applied to AASW samples. (a) Plot of the loadings on the PC1 versus PC2 factor plane; (b) plot of the loadings on the PC1 versus PC3 factor plane. Variables are indicated as: temperature $(\mathrm{T})$, salinity $(\mathrm{S})$, dissolved oxygen $\left(\mathrm{O}_{2}\right)$, fluorescence (FLUO), total alkalinity $\left(\mathrm{A}_{\mathrm{T}}\right)$, total inorganic carbon $\left(\mathrm{C}_{\mathrm{T}}\right), \mathrm{pH}_{\mathrm{in} \text { situ }}(\mathrm{pH})$, and $\mathrm{CO}_{2}$ partial pressure $\left(\mathrm{pCO}_{2}\right)$.

The score plots of PC1 versus PC2 and PC1 versus PC3 factor-planes (Figure 5) highlight that the samples collected in the AASW layer are ordered differently in relation to the sampling area and year, mainly for PC1 and PC3. With regards to sampling area variability, the samples collected at CA were characterized by colder temperature, lower $\mathrm{O}_{2}$ and fluorescence, and higher $\mathrm{C}_{\mathrm{T}}$ in comparison to those sampled in the other investigated areas. As regards the sampling year, the RIS area was characterized by higher $\mathrm{pH}$, fluorescence, and $\mathrm{O}_{2}$ values in 2012, unlike in 2006; on the contrary, the TNBp, the RSp and CI experienced higher temperature and fluorescence in 2006 than in 2012 as well as a wide dispersion of the carbonate system data (cf. Table 2). Finally, PCA did not show any differences between the 2006 and 2012 samples collected at CA since these lie in the same quadrant of the score plot. 


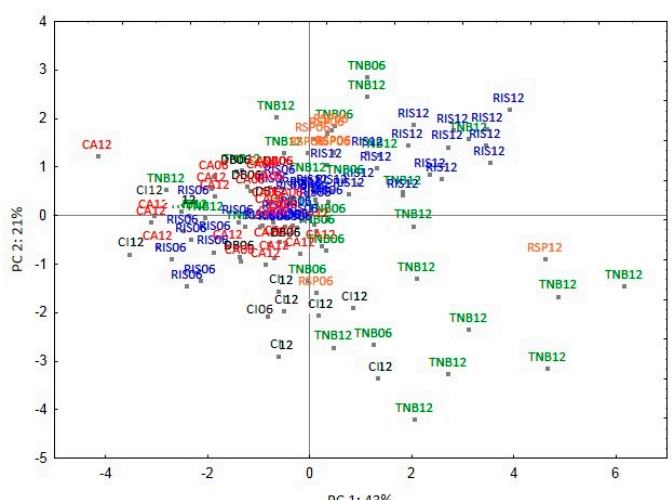

(a)

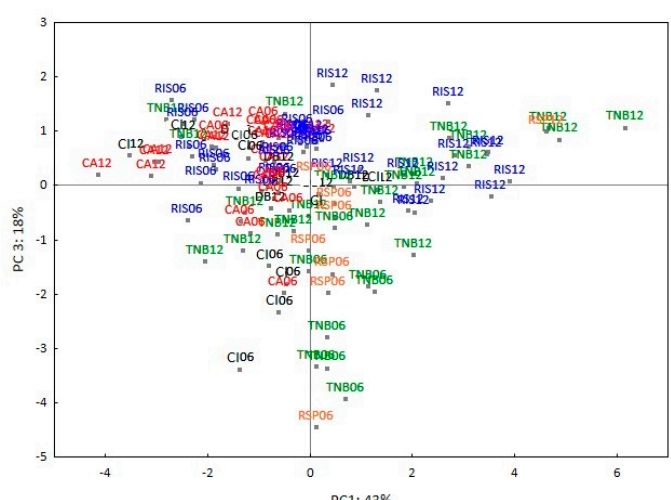

(b)

Figure 5. Scores plot of PC1 versus PC2 factor plane (a); scores plot of PC1 versus PC3 factor plane (b). The sampling stations have different abbreviations and colors according to the sampling areas (CA red: Cape Adare; CI black: Coulman Island; TNB green: Terra Nova Bay polynya; RSp orange: Ross Sea polynya; RIS blue: Ross ice shelf).

\subsection{Satellite Data}

Ice concentration maps were used to describe the basin scale variability of sea ice coverage before and during the sampling periods in 2006 and 2012. Disappearance of sea ice over the study area was slower in 2012 than in 2006. In mid-January 2012 a sea ice belt was still present at $68^{\circ} \mathrm{S}-70^{\circ} \mathrm{S}$, while the coastal areas near the Drygalski ice tongue and the TNBp $\left(\sim 74^{\circ} \mathrm{S}\right)$ were affected by the presence of sea ice with a patchy distribution. In both years, almost all sea ice had disappeared by mid-February (Figure 6).

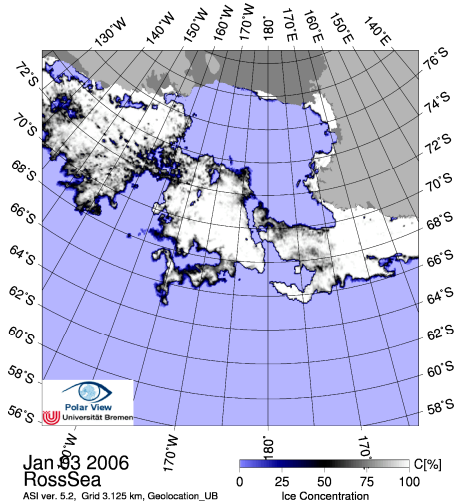

(a)

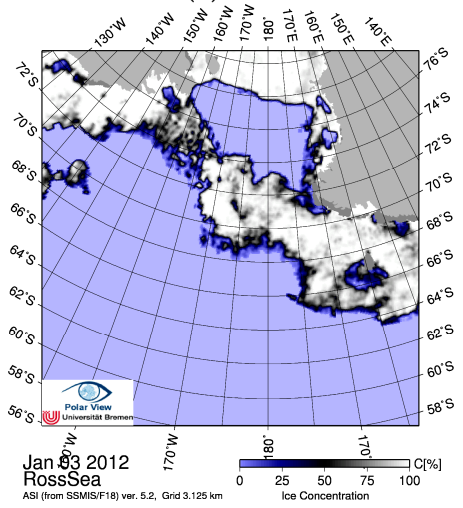

(d)

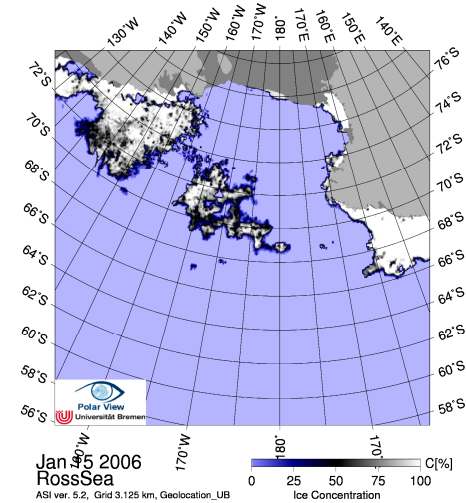

(b)

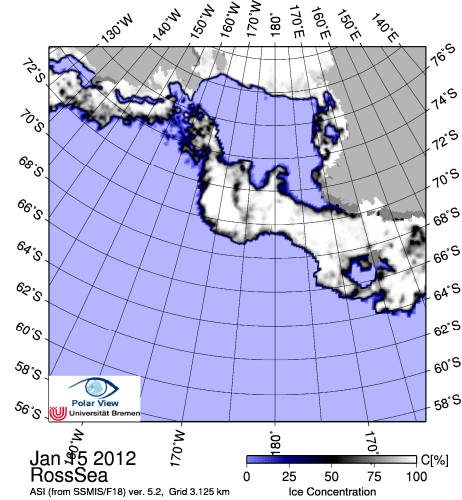

(e)

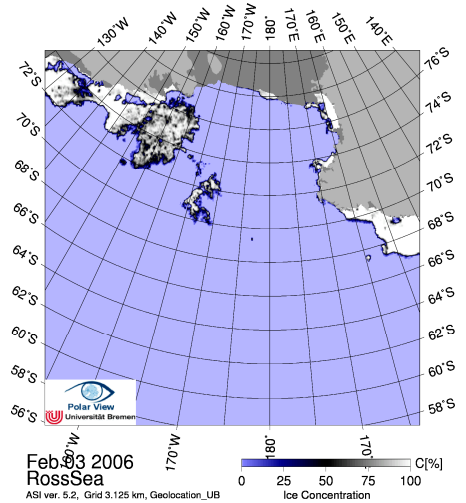

(c)

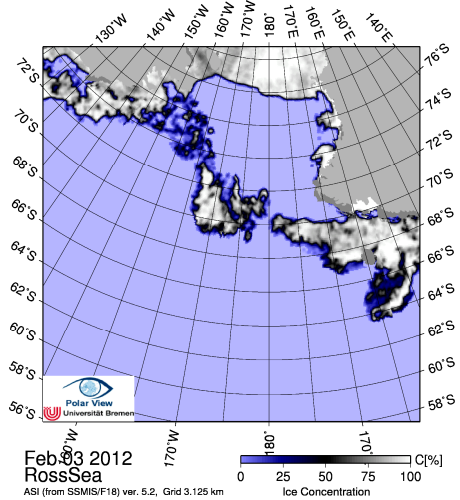

(f)

Figure 6. Sea ice concentration on 3 and 15 January, and 3 February, for 2006 ((a-c), respectively), and $2012((\mathbf{d}-\mathbf{f})$, respectively). Blue area is open water and white is $100 \%$ sea-ice concentration. 
MODIS satellite data show the presence of large areas of high Chl-a concentration levels in the Ross Sea shelf area both in February 2006 and 2012. The monthly composite maps show that maxima were confined to the TNBp and RSp for both years and along the RIS in 2012. Conversely, the area near CA displayed a low signal for both years (Figure 7).

Remotely sensed Chl-a concentration data referring to the position of the sampling stations obtained from the 8-day composites closest to the sampling stations have been correlated with the data of carbonate system parameters collected at the surface (Figure 8). No correlation was found for the 2006 samples, whereas for the 2012 samples the Chl-a co-varied positively and significantly with $\mathrm{pH}$ (Pearson's $\mathrm{r}=0.73, \mathrm{n}=28$ ) and negatively with $\mathrm{C}_{\mathrm{T}}$ (Pearson's $\mathrm{r}=-0.56, \mathrm{n}=28$ ). Figure 8 shows the relationship between Chl-a and $\mathrm{C}_{\mathrm{T}}$ and between $\mathrm{Chl}-\mathrm{a}$ and $\mathrm{pH}$, respectively.

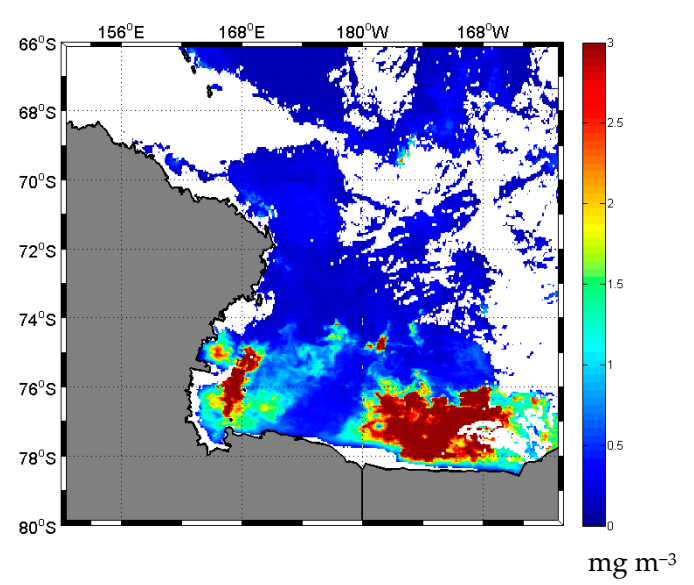

(a)

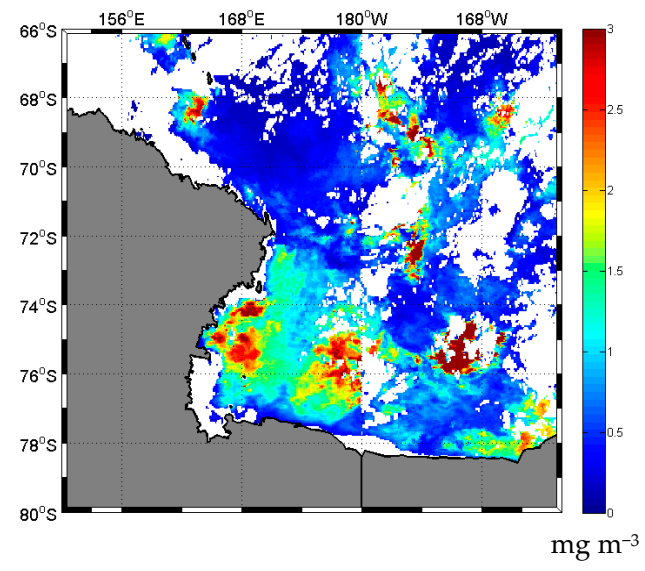

(b)

Figure 7. Monthly mean satellite chlorophyll concentrations in February 2006 (a) and in February 2012 (b) in the Ross Sea shelf area (Aqua MODIS product from 4 km Level 3) (http:/ / oceancolor.gsfc.nasa. gov/cgi/13).

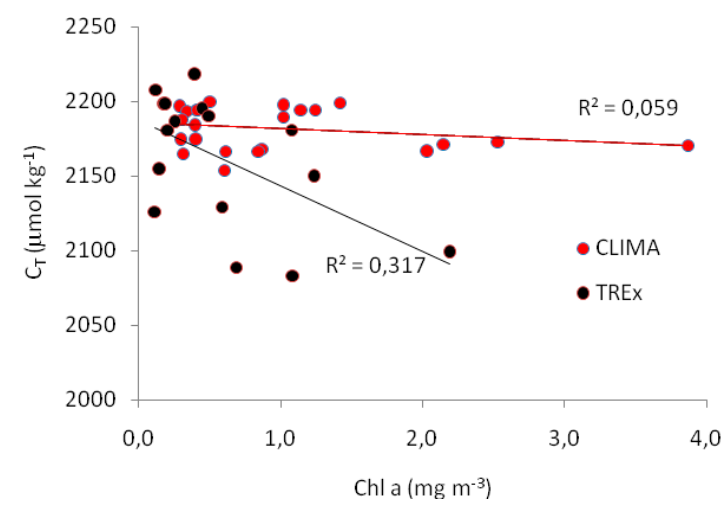

(a)

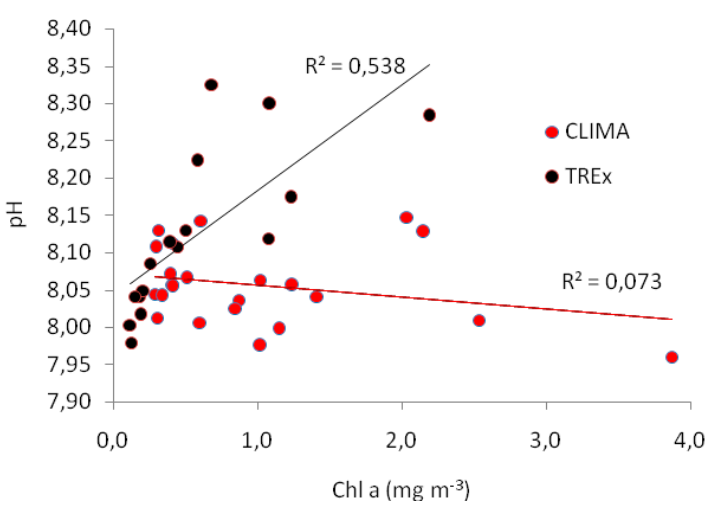

(b)

Figure 8. Surface total inorganic carbon (a) and $\mathrm{pH}(\mathbf{b})$ as a function of satellite chlorophyll-a (Chl-a) data. 


\section{Discussion}

\subsection{Physically-Induced Variability of the Carbonate System in the AASW}

The CLIMA and T-REx cruises covered the shelf region and the western slope area of the Ross Sea and were both characterized by ice-free conditions over most of the study area. Results from both cruises show an increase of AASW layer thickness and of ML depth from the TNBp towards the RIS and CA. The observed deepening of the ML and the increased AASW layer thickness have been associated with a decrease in water column stability $[12,39,50]$. Besides the observed spatial variability, the AASW thickness also increased from 2006 to 2012 over all areas. By contrast, the ML depths showed non-homogeneous behaviour. An increase of ML depth in CA and the RIS and a decrease in the RSp area were observed, while the TNBp and CI showed a similar ML value during both cruises. Similarly to the physical properties, the carbonate system properties of AASW showed a large variability likely to be influenced by the sea ice extent and evolution. The longer lasting presence of sea ice in 2012 implies that the sea ice melting was still influencing upper AASW layer properties during the cruise period. This agrees with lower temperature and salinity and consequently with the higher MW\% measured in the January 2012 samples collected in the TNBp and CI transects. On the other hand, the lower variability of the AASW features observed in the CA sampling area (centred at about $72^{\circ} \mathrm{S}$ ) can be linked to the similarities in sea ice distribution in both years.

Sea ice concentration variability can be modulated by various factors, from the local to large scales. The main large-scale modes that dominate Southern Hemisphere atmospheric variability are the Southern Annular Mode (SAM) and the two Pacific-South American modes associated with the high latitude response to the El Niño-Southern Oscillation [51,52]. The influence of these climate oscillations on sea ice retreat and advance has been observed both in the Antarctic Peninsula and in the Ross Sea [25,53-55]. Sea ice export from the Ross Sea is also related to the strength of the Amundsen Sea low pressure field which is in turn related to large-scale SO climatic patterns [56]. Cold southerly winds are found in the Ross Sea during SAM+ events which contribute to positive sea ice anomalies [53]. Moreover, cold conditions and more sea ice in the Amundsen and Ross Seas are associated with the strengthening of the polar front jet that occurs during La Niña events [53]. Amplified effects on both physical and biological water column properties can be observed when SAM+ coincides with La Niña [57], as occurred in 2012. Thus, the later spring sea ice retreat observed in 2012 was likely linked to the different interactions and effects of the two climate modes on the Ross Sea area $[25,26,55]$. Consequently, the addition of melting freshwater in 2012 resulted in a dilution of $A_{T}$ and $C_{T}$. This is consistent with the fact that the distribution of surface $A_{T}$ and $C_{T}$ is controlled by factors linked to $S$, as the positive and significant correlation found between these parameters pointed out. The lowest $S$ $(\approx 33.00)$ measured in 2012 in the TNBp coincided with the lowest $A_{T}$ and $C_{T}$ concentrations. The effect of freshwater addition had a greater impact on $A_{T}$ than on $C_{T}$, as highlighted by the correlation values and the PCA results. The effects produced by ice melting on the carbonate system have been already documented in the Arctic Ocean [58] as well as in the Southern Ocean, where low $\mathrm{A}_{\mathrm{T}}, \mathrm{C}_{\mathrm{T}}, \mathrm{pH}$, and $\Omega$ values were observed in the sea-ice covered areas in both the Amundsen Sea and Ross Sea [21,33]. In this study a significant negative correlation between $\mathrm{MW} \%, \Omega$, and $\mathrm{pH}$ was only found in 2006 . This suggests that in 2012 an additional forcing could have determined the displacement of carbonate equilibria and the $\Omega_{\mathrm{Ar}}$ distribution (Figure 9) in spite of the greater contribution of sea ice melting to the surface waters. 


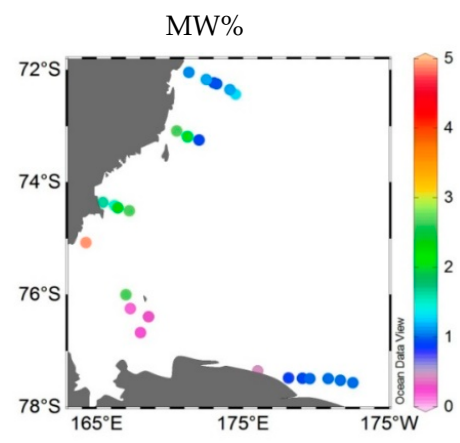

(a)

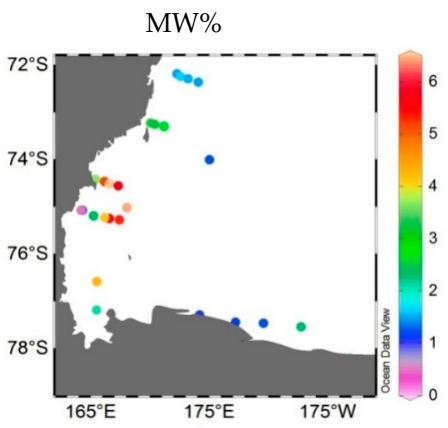

(d)

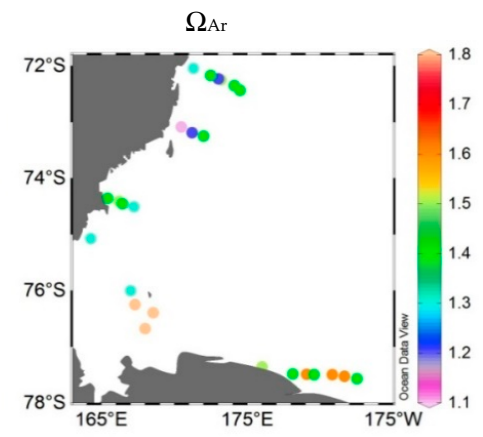

(b)

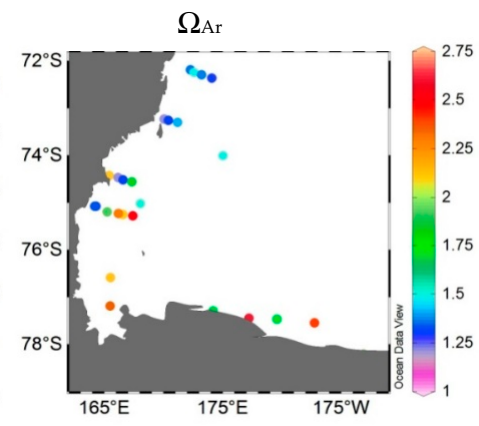

(e)

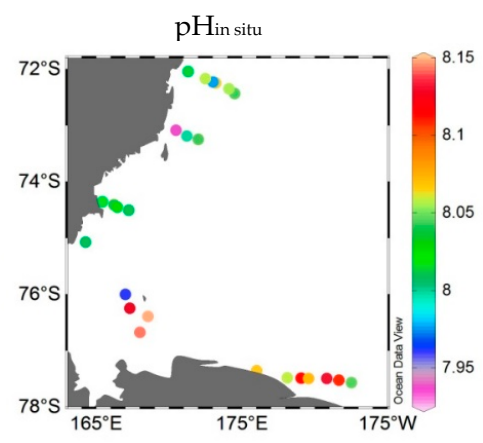

(c)

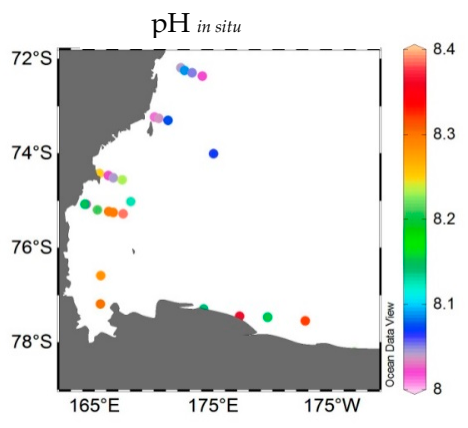

(f)

Figure 9. Surface distribution of melt water percentage, aragonite saturation state and $\mathrm{pH}_{\text {in situ }}$ in 2006 $((\mathbf{a}-\mathbf{c})$, respectively) and $2012((\mathbf{d}-\mathbf{f})$, respectively).

Prior to this study, an increase in $\mathrm{C}_{\mathrm{T}}$ and a $\mathrm{pH}$ decrease due to the intrusion of $\mathrm{CDW}$ into the shelf in the western Ross Sea had been already observed [18,33]. In this study, the CDW was traced exclusively to CA in 2006, and could have influenced the carbonate properties. However, since the presence of $\mathrm{CDW}$ in the other investigated areas has not been detected, we believe that this factor is not relevant in conditioning the observed variability in the AASW across the entire shelf area.

\subsection{Biologically-Induced Variability of the Carbonate System in the AASW}

Biological processes are strictly dependent on the sea-ice cover, light availability, and water column stratification [39]. Late spring 2012 sea ice retreat resulted in a higher freshwater presence in the TNBp and RSp, and along the RIS. This supported a more intense bloom throughout the increased stratification of the water column and the input of iron reservoirs from the ice sheet [59-61]. This agrees with the increase in the mean annual Chl-a concentration on the Ross Sea shelf observed during a SAM+ or La Niña event $[9,62]$. Thus, the variability in sea-ice extent and melting indirectly affect the carbonate system through biological forcing. Photosynthetic uptake of carbon by phytoplankton in the surface layer decreases $\mathrm{C}_{\mathrm{T}}$ while increasing $\mathrm{pH}, \Omega_{\mathrm{Ar}}$, and $\mathrm{O}_{2}$. Consistent with this observation, the $\mathrm{O}_{2}$ saturation (i.e., the ratio of the measured concentration to the concentration at the equilibrium, which is a function of temperature and salinity) was $\approx 100 \%$ or higher in the TNBp and RSp, whereas in the CA area it decreased to $75-79 \%$ on average. In the RIS region a significant difference was observed between the two surveys: $\mathrm{O}_{2}$ saturation ranged from $78 \% \pm 5$ in 2006 to $97 \% \pm 8$ in 2012, supporting the hypothesis that higher photosynthetic activity was occurring during the T-REx survey. The RIS area was also characterized by higher $\mathrm{pH}$ and fluorescence and by lower $\mathrm{C}_{\mathrm{T}}$ values in 2012 than in 2006, suggesting that a stronger control by biological activity compared to physical forcing was occurring within seasonal carbonate system variation. Chl-a concentrations in surface waters estimated by MODIS satellite data were in good agreement with these findings and allowed us to better explain the variability of the carbonate system properties in surface waters.

The phytoplankton of the Ross Sea are alternatively dominated by two functional groups, diatoms and haptophytes (i.e., Phaeocystis antarctica), which are typically separated both in space and time [10]. 
In the summer, diatoms usually comprise $90 \%$ of the phytoplankton along the western Ross Sea continental shelf and in the TNBp, where the stratification of surface waters associated with ice melting results in a relatively shallow mixed layer $[10,41]$.

Information about phytoplankton community composition cannot be obtained by looking at the MODIS satellite Chl-a concentration maps, and unfortunately no specific data were collected during the T-REx (2012) cruise. The observations from the CLIMA survey showed that diatoms prevailed [63], and considering the removal of macronutrients (nitrate, phosphate, and silicate (data not shown)), some assumptions can be made for T-REx. The drawdown of $\mathrm{C}, \mathrm{N}$, and $\mathrm{P}$ deviates substantially from Redfield ratios (106:16:1) [64], indicating marked phytoplankton taxonomic variation [17,65]. In both years, the N:P ratios (13 and 11, respectively) observed in our study fall within the range of values reported for diatom-dominated waters [66]. This is in agreement with the development of phytoplankton assemblages proposed for the Ross Sea [10]. Similarly, the slope of the $\mathrm{C}_{\mathrm{T}}: \mathrm{PO}_{4}$ disappearance ratio (76.6) falls within the range proposed for diatom-dominated waters (94.3 \pm 20.1$)$ [66].

During the 2006 cruise, the mean sea surface $\mathrm{pCO}_{2}\left(\mathrm{pCO}_{2 \mathrm{sw}}\right)$ values exceeded the atmospheric value in the TNBp, CI, and CA areas, whereas the opposite was observed in the RSp and along the RIS. On the contrary, $\mathrm{pCO}_{2 \mathrm{SW}}$ during the 2012 cruise was near or below the atmospheric saturation in all the surveyed areas (Table 2). Consequently, the mean $\triangle \mathrm{pCO}_{2}\left(\mathrm{pCO}_{2 \mathrm{SW}}-\mathrm{pCO}_{2}\right.$ air $)$ was negative (from -3 to $-185 \mu \mathrm{atm}$ ) and in those stations where the greatest air-sea $\mathrm{CO}_{2}$ disequilibrium occurred, the highest $\mathrm{pH}$ and $\mathrm{O}_{2}$ super-saturation was observed. Thus, the sea surface was under-saturated with respect to atmospheric $\mathrm{CO}_{2}$ as biological carbon uptake reduced seawater $\mathrm{pCO}_{2}$ and $\mathrm{C}_{\mathrm{T}}$, creating $\mathrm{CO}_{2}$ sinks. However, it should be mentioned that even though disequilibria occur, this does not mean that atmospheric $\mathrm{CO}_{2}$ enters the ocean quickly, as the time scale of air-sea exchange relative to drawdown is different. Sea-air $\mathrm{CO}_{2}$ fluxes varied substantially by becoming positive or negative, accordingly to the sign of the calculated $\triangle \mathrm{pCO}_{2}$ (Figure 10).

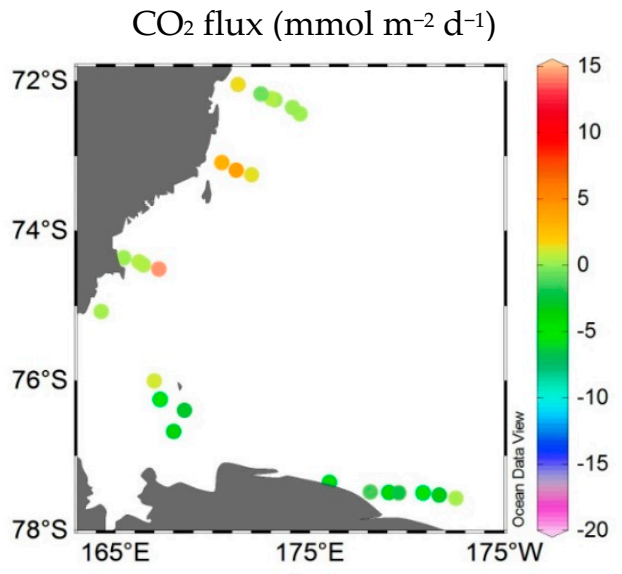

(a)

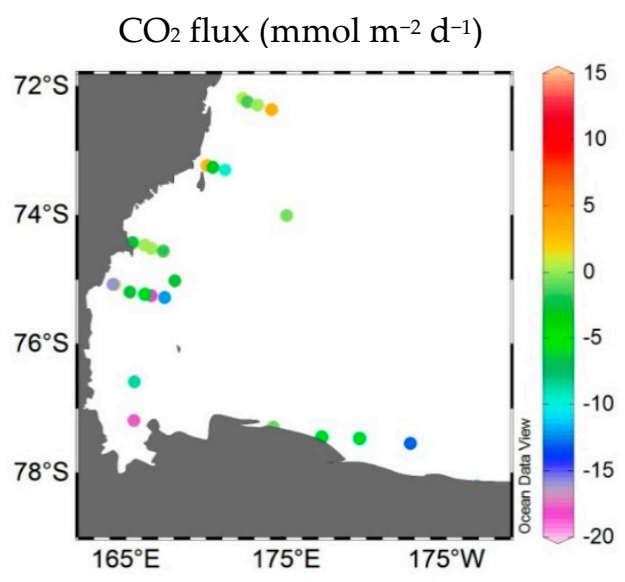

(b)

Figure 10. Surface distribution of $\mathrm{CO}_{2}$ flux $\left(\mathrm{mmol} \mathrm{m}^{-2} \mathrm{~d}^{-1}\right)$ in 2006 (a) and 2012 (b).

The highest negative values, comparable to those estimated by [37], were observed in the TNBp and along the RIS in $2012\left(-18.4\right.$ and $\left.-13.2 \mathrm{mmol} \mathrm{m}^{-2} \mathrm{~d}^{-1}\right)$, suggesting that these areas were acting as a sink of $\mathrm{CO}_{2}$. Wind anomalies associated with the SAM+ can impact the flux of $\mathrm{CO}_{2}$ between the atmosphere and the sea surface, since air-sea $\mathrm{CO}_{2}$ flux is directly influenced by wind speed. In the present study, there was no evidence of correlation between wind speeds and $\mathrm{CO}_{2}$ fluxes; in fact, even when high wind speeds were measured, the flux could be weak. However, our data are limited both in time and space and wind anomalies can alter on a longer time scale the circulation and the biogeochemistry of the area. Nevertheless, the effect of SAM+ on air-sea $\mathrm{CO}_{2}$ flux variability is expected to be only moderate [67]. 


\section{Conclusions}

Our results show the seasonal influence of both sea ice melting and biological production in driving summertime AASW carbonate system variability in the western Ross Sea. The combination of in situ and satellite data was crucial to understanding the investigated phenomena. This study highlights the pivotal role of sea ice melting in controlling both directly and indirectly the carbonate system chemistry of the mixed layer. During both investigated years, the freshwater input from sea ice melting contributed to stratifying the water column and led to the dilution of $A_{T}$ and $C_{T}$ as well as to a decrease in $\mathrm{pH}$ and $\Omega_{\mathrm{Ar}}$. The sea ice melting exerted a stronger direct control on the surface water carbonate system parameters in 2006 than in 2012 even though the melting water percentage was lower. On the contrary, the sea ice melting indirectly affected the carbonate system in 2012 through biological forcing because it facilitated the development of phytoplankton blooms. This resulted in high $\mathrm{pH}$ and $\Omega_{\mathrm{Ar}}$ and in low $\mathrm{C}_{\mathrm{T}}$, particularly in those areas where high Chl-a concentration was shown by satellite maps. As a result of climate change, the Ross Sea is experiencing a general cooling of the region, higher variability of sea ice properties, and changes in water masses characteristics. This could influence the timing of phytoplankton blooms and therefore affect biogeochemical cycling. Thus, the productive coastal sea-ice zones of the Ross Sea are key regions with which to study the response of marine ecosystems to the impacts of $\mathrm{CO}_{2}$ increases in the atmosphere. In order to verify the existence and evaluate the magnitude of any trend in long term changes of the carbonate system in surface waters of the Ross Sea, it will be crucial to include both winter time measurements and further studies on the modulation of ENSO and SAM.

Author Contributions: Conceptualization, P.R.; Data curation, P.R., C.I., L.R., C.M., S.S., P.C., Y.C. and P.F.; Funding acquisition, P.R. and P.F.; Methodology, P.R., C.I. and Y.C.; Visualization, P.C. and Y.C.; Writing-Original draft, P.R.; Writing-Review \& editing, C.I., L.R., C.M., S.S., P.C., Y.C. and P.F.

Funding: This research was funded by the Italian National Program for Antarctic Research, grant number 2004/8.3, 2009/A2.04, 2016/B2.01, and PNRA16_00207.

Acknowledgments: Extended thanks are given to the scientific party, captain, officers, and crew onboard R.V. Italica for the support given during the CLIMA and T-REx cruises. We are grateful to anonymous referees for their suggestions. We thank Mrs. Donatella Cillo for English editing.

Conflicts of Interest: The authors declare no conflict of interest.

\section{References}

1. Sabine, C.L.; Feely, R.A.; Gruber, N.; Key, R.M.; Lee, K.; Bullister, J.L.; Wanninkhof, R.; Wong, C.S.; Wallace, D.W.R.; Tilbrook, B.; et al. The oceanic sink for anthropogenic $\mathrm{CO}_{2}$. Science 2004, 305, 367-371. [CrossRef] [PubMed]

2. Jones, E.M.; Fenton, M.; Meredith, M.P.; Clargo, N.M.; Ossebaar, S.; Ducklow, H.W.; Venables, H.J.; de Baar, H.J.W. Ocean acidification and calcium carbonate saturation states in the coastal zone of the West Antarctic Peninsula. Deep-Sea Res. Part II 2017, 139, 181-194. [CrossRef]

3. Feely, R.A.; Sabine, C.L.; Lee, K.; Berelson, W.; Kleypas, J.; Fabry, V.J.; Millero, F.J. Impact of anthropogenic $\mathrm{CO}_{2}$ on the $\mathrm{CaCO}_{3}$ system in the oceans. Science 2004, 305, 362-366. [CrossRef] [PubMed]

4. Cao, L.; Caldeira, K.; Jain, A.K. Effects of carbon dioxide and climate change on ocean acidification and carbonate mineral saturation. Geophys. Res. Lett. 2007, 34, L05607. [CrossRef]

5. Orr, J.C.; Fabry, V.J.; Aumont, O.; Bopp, L.; Doney, S.C.; Feely, R.A.; Gnanadesikan, A.; Gruber, N.; Ishida, A.; Joos, F.; et al. Anthropogenic ocean acidification over the twenty-first century and its impact on calcifying organisms. Nature 2005, 437, 681-686. [CrossRef] [PubMed]

6. Feely, R.; Doney, S.; Cooley, S. Ocean Acidification: Present conditions and future changesin a high- $\mathrm{CO}_{2}$ world. Oceanography 2009, 22, 36-47. [CrossRef]

7. Manno, C.; Sandrini, S.; Tositti, L.; Accornero, A. First stages of degradation of Limacina helicina shells observed above the aragonite chemical lysocline in Terra Nova Bay (Antarctica). J. Mar. Syst. 2007, 68, 91-102. [CrossRef] 
8. Bednaršek, N.; Tarling, G.A.; Bakker, D.C.E.; Fielding, S.; Jones, E.M.; Venables, H.J.; Ward, P.; Kuzirian, A.; Lézé, B.; Feely, R.A.; et al. Extensive dissolution of live pteropods in the Southern Ocean. Nat. Geosci. 2012, 5, 881-885. [CrossRef]

9. Schine, C.M.S.; van Dijken, G.L.; Arrigo, K.R. Spatial analysis of trends in primary production and relationship with large-scale climate variability in the Ross Sea, Antarctica (1997 \pm 2013$)$. J. Geophys. Res. Oceans 2016, 121, 368-386. [CrossRef]

10. Smith, W.O., Jr.; Ainley, D.G.; Arrigo, K.R.; Dinniman, M.S. The Oceanography and Ecology of the Ross Sea. Annu. Rev. Mar. Sci. 2014, 6, 469-487. [CrossRef]

11. Budillon, G.; Pacciaroni, M.; Cozzi, S.; Rivaro, P.; Catalano, G.; Ianni, C.; Cantoni, C. An optimum multiparameter mixing analysis of the shelf waters in the Ross Sea. Antarct. Sci. 2003, 15, 105-118. [CrossRef]

12. Orsi, A.H.; Wiederwohl, C.L. A recount of Ross Sea waters. Deep-Sea Res. Part II 2009, 56, 778-795. [CrossRef]

13. Arrigo, K.R.; van Dijken, G.; Long, M. Coastal Southern Ocean: A strong anthropogenic $\mathrm{CO}_{2}$ sink. Geophys. Res. Lett. 2008, 35, L21602. [CrossRef]

14. Caldeira, K.; Duffy, P.B. The role of the Southern Ocean in uptake and storage of anthropogenic carbon dioxide. Science 2000, 287, 620-622. [CrossRef]

15. Tortell, P.D.; Guéguen, C.; Long, M.C.; Payne, C.D.; Leeand, P.; Di Tullio, G.R. Spatial variability and temporal dynamics of surface water $\mathrm{pCO}_{2}, \Delta \mathrm{O}_{2} /$ Ar and dimethylsulfide inthe Ross Sea, Antarctica. Deep-Sea Res. Part II 2011, 58, 241-259. [CrossRef]

16. Bates, N.R.; Hansell, D.A.; Carlson, C.A.; Gordon, L.I. Distribution of $\mathrm{CO}_{2}$ species, estimates of net community production, and air-sea $\mathrm{CO}_{2}$ exchange in the Ross Sea polynya. J. Geophys. Res. 1998, 103, 2883-2896. [CrossRef]

17. Sweeney, C.; Hansell, D.A.; Carlson, C.A.; Codispoti, L.A.; Gordon, L.I.; Marra, J.; Millero, F.J.; Smith, W.O., Jr.; Takahashi, T. Biogeochemical regimes, net community production and carbon export in the Ross Sea, Antarctica. Deep-Sea Res. Part II 2000, 47, 3369-3394. [CrossRef]

18. Sandrini, S.; Aït-Ameur, N.; Rivaro, P.; Massolo, S.; Touratier, F.; Tositti, L.; Goyet, C. Anthropogenic carbon distribution in the Ross Sea (Antarctica). Antarct. Sci. 2007, 19, 395-407. [CrossRef]

19. Kapsenberg, L.; Kelley, A.L.; Shaw, E.C.; Martz, T.R.; Hofmann, G.E. Near-shore Antarctic pH variability has implications for the design of ocean acidification experiments. Sci. Rep. 2015, 5, 9638-9647. [CrossRef]

20. Rivaro, P.; Ianni, C.; Langone, L.; Ori, C.; Aulicino, G.; Cotroneo, Y.; Saggiomo, M.; Mangoni, O. Physical and biological forcing of mesoscale variability in the carbonate system of the Ross Sea (Antarctica) during summer 2014. J. Mar. Syst. 2017, 166, 144-168. [CrossRef]

21. Mattsdotter Björk, M.; Fransson, A.; Torstensson, A.; Chierici, M. Ocean acidification state in western Antarctic surface waters: Controls and interannual variability. Biogeosciences 2014, 11, 57-73. [CrossRef]

22. Conrad, C.J.; Lowenduski, N. Climate-driven variability in the Southern Ocean carbonate system. J. Clim. 2015, 28, 5335-5350. [CrossRef]

23. Buongiorno Nardelli, B.; Guinehut, S.; Verbrugge, N.; Cotroneo, Y.; Zambianchi, E.; Iudicone, D. Southern Ocean mixed layer seasonal and interannual variations from combined satellite and in situ data. J. Geophys. Res. Oceans 2017, 122, 10042-10060. [CrossRef]

24. Cerrone, D.; Fusco, G.; Cotroneo, Y.; Simmonds, I.; Budillon, G. The Antarctic Circumpolar Wave: Its presence and interdecadal changes during the last 142 Years. J. Clim. 2017, 30, 6371-6389. [CrossRef]

25. Cerrone, D.; Fusco, G.; Simmonds, I.; Aulicino, G.; Budillon, G. Dominant covarying climate signals in the Southern Ocean and Antarctic sea ice influence during the last three decades. J. Clim. 2017, 30, 3055-3072. [CrossRef]

26. Fusco, G.; Cotroneo, Y.; Aulicino, G. Different behaviors of the Ross and Weddell Seas surface heat fluxes in the period 1972-2015. Climate 2018, 6, 17. [CrossRef]

27. Aulicino, G.; Cotroneo, Y.; Ruiz, S.; Román, A.S.; Pascual, A.; Fusco, G.; Tintoré, J. Monitoring the Algerian Basin through glider observations, satellite altimetry and numerical simulations along a SARAL/AltiKa track. J. Mar. Syst. 2018, 179, 55-71. [CrossRef]

28. Cotroneo, Y.; Budillon, G.; Fusco, G.; Spezie, G. Cold core eddies and fronts of the Antarctic Circumpolar Current south of New Zealand from in situ and satellite data. J. Geophys. Res. 2013, 118, 2653-2666. [CrossRef]

29. Cotroneo, Y.; Aulicino, G.; Ruiz, S.; Pascual, A.; Budillon, G.; Fusco, G.; Tintoré, J. Glider and satellite high resolution monitoring of a mesoscale eddy in the Algerian basin: Effects on the mixed layer depth and biochemistry. J. Mar. Syst. 2015, 162, 73-88. [CrossRef] 
30. Dickson, A.G.; Sabine, C.L.; Christian, J.R. (Eds.) Guide to Best Practices for Ocean $\mathrm{CO}_{2}$ Measurements. PICES Spec. Publ. 2007, 3, 191. [CrossRef]

31. Edmond, J.M. High precision determination of titration alkalinity and total carbon dioxide content of seawater by potentiometric titration. Deep-Sea Res. 1970, 17, 737-750.

32. Rivaro, P.; Messa, R.; Massolo, S.; Frache, R. Distributions of carbonate properties along the water column in the Mediterranean Sea: Spatial and temporal variations. Mar. Chem. 2010, 121, 236-245. [CrossRef]

33. Rivaro, P.; Messa, R.; Ianni, C.; Magi, E.; Budillon, G. Distribution of total alkalinity and pH in the Ross Sea (Antarctica) waters during austral summer 2008. Polar Res. 2014, 33, 20403. [CrossRef]

34. Pierrot, D.; Lewis, E.; Wallace, D.W.R. MS Excel Program developed for $\mathrm{CO}_{2}$ system calculations, ORNL/CDIAC-105; Carbon Dioxide Information Analysis Center, Oak Ridge National Laboratory, US Department of Energy: Oak Ridge, TN, USA, 2006. [CrossRef]

35. Millero, F.J.; Pierrot, D.; Lee, K.; Wanninkhof, R.; Feely, R.A.; Sabine, C.L.; Key, R.M.; Takahashi, T. Dissociation constants for carbonic acid determined from field measurements. Deep Sea Res. I 2002, 49, 1705-1723. [CrossRef]

36. Wanninkhof, R. Relationship between wind speed and gas exchange over the ocean. J. Geophys. Res. Oceans 1992, 97, 7373-7382. [CrossRef]

37. SCOR Working Group 51. The acquisition, calibration, and analysis of CTD data. UNESCO Tech. Pap. Mar. Sci. 1988, 54, 102.

38. Fofonoff, N.P.; Millard, R.C., Jr. Algorithms for the computation of fundamental properties of seawater. UNESCO Tech. Pap. Mar. Sci. 1983, 44, 53.

39. Rivaro, P.; Ianni, C.; Magi, E.; Massolo, S.; Budillon, G.; Smethie, W.M., Jr. Distribution and ventilation of water masses in the western Ross Sea inferred from CFC measurements. Deep-Sea Res. I 2015, 97, 19-28. [CrossRef]

40. Mitchell, B.G.; Holm-Hansen, O. Observation and modelling of the Antarctic phytoplankton crop in relation to mixing depth. Deep Sea Res. I 1991, 38, 981-1007. [CrossRef]

41. Mangoni, O.; Saggiomo, V.; Bolinesi, F.; Margiotta, F.; Budillon, G.; Cotroneo, Y.; Misic, C.; Rivaro, P.; Saggiomo, M. Phytoplankton blooms during austral summer in the Ross Sea, Antarctica: Driving factors and trophic implications. PLoS ONE 2017, 12, e0176033. [CrossRef]

42. Farnham, I.M.; Johannesson, K.H.; Singh, A.K.; Hodge, V.F.; Stetzenbach, K.J. Factor analytical approaches for evaluating groundwater trace element chemistry data. Anal. Chim. Acta 2003, 490, 123-138. [CrossRef]

43. Schlitzer, R. Ocean Data View 2015. Available online: http:/ / odv.awi.de/ (accessed on 16 April 2016).

44. Spreen, G.; Kaleschke, L.; Heygster, G. Sea ice remote sensing using AMSR-E 89 GHz channels. J. Geophys. Res. 2008, 113, C02S03. [CrossRef]

45. Jackett, R.; McDougall, T.J. A neutral density variable for the world's oceans. J. Phys. Oceanogr. 1997, 27, 237-263. [CrossRef]

46. Castagno, P.; Falco, P.; Dinniman, M.S.; Spezie, G.; Budillon, G. Temporal variability of the Circumpolar Deep Water inflow onto the Ross Sea continental shelf. J. Mar. Syst. 2017, 166, 37-49. [CrossRef]

47. Fusco, G.; Budillon, G.; Spezie, G. Surface heat fluxes and thermohaline variability in the Ross Sea and in Terra Nova Bay polynya. Cont. Shelf Res. 2009, 29, 1887-1895. [CrossRef]

48. Rusciano, E.; Budillon, G.; Fusco, G.; Spezie, G. Evidence of atmosphere-sea ice- ocean coupling in the Terra Nova Bay polynya Ross Sea-Antarctica. Cont. Shelf Res. 2013, 61-62, 112-124. [CrossRef]

49. DeJong, H.B.; Dunbar, R.B.; Mucciarone, D.A.; Koweek, D.A. Carbonate saturation state of surface waters in the Ross Sea and Southern Ocean: Controls and implications for the onset of aragonite undersaturation. Biogeosciences 2015, 12, 8429-8465. [CrossRef]

50. Massolo, S.; Messa, R.; Rivaro, P.; Leardi, R. Annual and spatial variations of chemical and physical properties in the Ross Sea surface waters (Antarctica). Cont. Shelf Res. 2009, 29, 2333-2344. [CrossRef]

51. Mo, K.C.; Ghil, M. Statistics and dynamics of persistent anomalies. J. Atmos. Sci. 1987, 44, 877-901. [CrossRef]

52. Fogt, R.L.; Bromwich, D.H.; Hines, K.M. Understanding the SAM influence on the South Pacific ENSO teleconnection. Clim. Dyn. 2011, 36, 1555-1576. [CrossRef]

53. Stammerjohn, S.E.; Martinson, D.G.; Smith, R.C.; Yuan, X.; Rind, D. Trends in Antarctic annual sea ice retreat and advance and their relation to El Niño-Southern Oscillation and Southern Annular Mode variability. J. Geophys. Res. 2008, 113, C03S90. [CrossRef] 
54. Parkinson, C.L. Southern Ocean sea ice and its wider linkages: Insights revealed from models and observations. Antarct. Sci. 2004, 16, 387-400. [CrossRef]

55. Cerrone, D.; Fusco, G. Low-Frequency Climate Modes and Antarctic Sea Ice Variations, 1982-2013. J. Clim. 2018, 31, 147-175. [CrossRef]

56. Raphael, M.N.; Marshall, G.J.; Turner, R.L.; Fogt, D.; Schneider, D.A.; Dixon, J.S.; Hosking, J.; Jones, M.; Hobbs, W.R. The Amundsen Sea low variability, change, and impact on Antarctic Climate. BAMS 2016, 97, 111-121. [CrossRef]

57. Soppa, M.; Völker, C.; Bracher, A. Diatom phenology in the Southern Ocean: Mean patterns, trends and the role of climate oscillations. Remote Sens. 2016, 8, 420. [CrossRef]

58. Chierici, M.; Fransson, A. $\mathrm{CaCO}_{3}$ saturation in the surface water of the Arctic Ocean: Undersaturation in freshwater influenced shelves. Biogeosciences 2009, 6, 2421-2432. [CrossRef]

59. Gerringa, L.J.A.; Laan, P.; van Dijken, G.L.; van Haren, H.; De Baar, H.J.W.; Arrigo, K.R.; Alderkamp, A.C. Sources of iron in the Ross Sea Polynya in early summer. Mar. Chem. 2015, 177, 447-459. [CrossRef]

60. Lannuzel, D.; Grotti, M.; Abelmoschi, M.L.; van der Merwe, P. Organic ligands control the concentrations of dissolved iron in Antarctic sea ice. Mar. Chem. 2015, 174, 120-130. [CrossRef]

61. Rivaro, P.; Ardini, F.; Grotti, M.; Aulicino, G.; Cotroneo, Y.; Fusco, G.; Mangoni, O.; Bolinesi, F.; Saggiomo, M.; Celussi, M. Mesoscale variability related to iron speciation in a coastal Ross Sea area (Antarctica) during summer 2014. Chem. Ecol. 2019, 35, 1-19. [CrossRef]

62. Arrigo, K.R.; Van Dijken, G.L. Annual changes in sea-ice, chlorophyll-a, and primary production in the Ross Sea, Antarctica. Deep-Sea Res. Part II 2004, 51, 117-138. [CrossRef]

63. Rivaro, P.; Abelmoschi, M.L.; Grotti, M.; Magi, E.; Margiotta, F.; Massolo, S.; Saggiomo, V. Combined effects of hydrographic structure and iron and copper availability on the phytoplankton growth in Terra Nova Bay Polynya (Ross Sea, Antarctica). Deep-Sea Res. Part I 2012, 62, 97-110. [CrossRef]

64. Redfield, A.C.; Ketchum, B.H.; Richards, F.A. The influence of organisms on the composition of seawater. In The Composition of Seawater. Comparative and Descriptive Oceanography. The Sea: Ideas and Observations on Progress in the Study of the Seas; Hill, M.N., Ed.; Wiley: New York, NY, USA, 1963; Volume 2, pp. $26-77$.

65. Dunbar, R.B.; Arrigo, K.R.; Lutz, M.; DiTullio, G.R.; Leventer, A.R.; Lizotte, M.P.; Van Woert, M.P.; Robinson, D.H. Non-Redfield production and export of marine organic matter: A recurrent part of the annual cycle in the Ross Sea, Antarctica. In Biogeochemistry of the Ross Sea; Antarctic Research Series; DiTullio, G.R., Dunbar, R.B., Eds.; American Geophysical Union: Washington, DC, USA, 2003; Volume 78, pp. 179-196.

66. Arrigo, K.R.; Robinson, D.H.; Worthen, D.L.; Dunbar, R.B.; DiTullio, G.R.; VanWoert, M.; Lizotte, M.P. Phytoplankton community structure and the drawdown of nutrients and $\mathrm{CO}_{2}$ in the Southern Ocean. Science 1999, 283, 365-367. [CrossRef] [PubMed]

67. Lovenduski, N.S.; Gruber, N. Impact of the Southern Annular Mode on Southern Ocean circulation and biology. Geophys. Res. Lett. 2005, 32, L11603. [CrossRef] 